\title{
Character Education Values That Work in Islamic Senior High School Setting
}

\author{
Muhammad Yaumi \& Rustam Husain \\ Post Graduate Program UINAM ; Universitas Negeri Gorontalo \\ muhammadyaumi@yahoo.com; oeetamz@yahoo.co.id
}

\begin{abstract}
The purpose of study is to discover the character education values that are integrated in lesson plan, implemented in the classroom setting, and classroom academic rules. This is a case study research that focused on describing the integration of character education program in the Model Islamic senior high school of Makassar, Indonesia. Fifty lesson plans were collected, twenty six informants were observed, and five informants were interviewed to have data on character education values that work. The data were analyzed using qualitative approach; data reduction, data display, conclusion, and verification. The result showed that (1) there are eighteen character education values written in the lesson plan; religious, honest, tolerant, discipline, hard working, creative, independent, democratic, curiosity, the spirit of nationalism, love to motherland, appreciation of achievement, friendly, peaceful, love to read, environmental and social care, responsibility, (2) the values that work in the classroom are religious, trustworthy, respectfulness, diligent, fair, care, integrity, responsible, honest, love to motherland, courage, and (3) the values that work in the academic rules are disciplines, care, tolerant, friendly, responsible.
\end{abstract}

Studi ini bertujuan untuk menemukan nilai-nilai pendidikan karakter yang diintegrasikan melalui Rencana Pelaksanaan Pembelajaran, diimplementasikan dalam pelaksanaan pembelajaran di kelas dan aturan akademik sekolah. Penelitian ini menggunakan metode studi kasus yang diarahkan pada pendeskripsian integrasi program pendidikan karakter pada Madasah Aliyah Negeri Model Makassar, Indonesia. Sebanyak 50 RPP dikumpulkan, duapuluh enam informan diamati, dan lima informan diwawancarai untuk memperoleh data tentang nilai-nilai karakter yang dijalankan. Data dianalisis dengan menggunakan pendekatan kualitiatif; reduksi data, penyajian data, verifikasi, dan pengambilan kesimpulan. Hasil penelitian menunjukkan bahwa (1) terdapat delapan belas karakter yang tertulis pada RPP mencakup religius, jujur, toleran, disiplin, kerja keras, kreatif, mandiri, demokratis, keingintahuan, semangat kebangsaan, cinta tanah air, menghargai prestasi, bersahabat, cinta damai, gemar membaca, peduli lingkungan, peduli sosial, dan bertanggungjawab, (2) nilainilai karakter yang diintegrasikan dalam ruang kelas adalah religius, amanah, hormat, rajin, adil, peduli, integritas, bertanggungjawab, jujur, cinta tanah air, keberanian, dan (3) nilai-nilai karakter dalam penegakkan aturan sekolah adalah disiplin, peduli, toleran, bersahabat, dan bertanggungjawab.

Keywords: Character Education; Value; Academic Rules 


\section{A. Introduction}

Character education as we understand today does not appear abruptly, it does not come merely to respond to the moral condition of the generation who tend to be oriented material rather than value. But the root of character education has been existing along with the establishment and development of human psychology and civilization. Psychologically, Dewantara describes the relationship between the soul and human character. The character is a unification of all permanent human natures that become a special sign to distinguish people from one another. The specificity of the sign depends on the spirit generated by the soul (psychotherapy), in which the human soul is formed from the combination of thought, feeling, and volition (or cipta, rasa, dan karsa in Javenese). ${ }^{1}$

In order to understand the relationship between the soul and character, a parable was given like when people look at the goods (stuff), then there arises the mind to further observe thestuff (maybe asking of what the stuff is?, for what it is, how to make it, etc.).Then the feeling of pleasure or displeasure of the goods will arise. The desire will come under the influence of mind and feeling which later becomes a permanent desire. The desire is not necessarily induce a spirit, it depends on the character. Because of the character is a permanent balance between the principle of psychotherapy (soul) and external deed, the goodness or badness of person's temperament depends on the quality of human mysticism, namely soul and the objects outside the soul,which are always influential. $^{2}$

The positive psychologist like Martin E.P. Seligman and Mihaly Csikszentmihalyi focus their attention on character development by identifying the character as one of the pillars of the new branch of science, positive psychology. Mihaly Csikszentmihalyi is a psychologist who has written about creativity, finding flow, good work, good business, and others. The character values in positive psychology can be studied through three levels, namely (1) subjective level, (2) individual level, (3) group level. First, at the subjective level, the character values that can appear are prosperity,happiness and satisfaction. Those values are the result of the efforts that have been achieved in the past, and when

\footnotetext{
${ }^{1}$ Kihajar Dewantara, Pendidikan, (Cet. 2: Yogyakarta: Majelis Luhur Persatuan Taman Siswa, 1977), p. 407-410.

${ }^{2}$ Ibid., p. 409.
} 
these values are achieved, the happiness will appear. ${ }^{3}$ Second, character valuesat the individual level are the capacity of individual talent and love, determination, interpersonal skills, refinement, perseverance, or the ability to forgive others. Third, at the group level as well as a good of a citizen or an organization that drives individuals to become good citizens, the character values that appear are the responsibility, maintenance, concerned with the public interest, propriety, modesty, tolerance, and work ethic.

In mid 20 century, many psychological studies were devoted to the problems of depression, racism, violence, self-managing, irrationality, and matters related to psychological distress, but did not devote much attention to the strength of character, kindness and happiness. Therefore, the positive psychology felt important to come up with the quality of the characters. These are motivated by three basic faiths (1) mission, (2) standards, and (3) identity. ${ }^{4}$ Each realm of work has a central mission, which reflects a basic societal need and which the practitioner should feel committed to realizing. Likewise each profession prescribes standards of performance, some permanent, some changing with time and place. The last is identity, the central element of identity is moral, where people must determine for themselves what lines they will not cross and why they will not cross them. ${ }^{5}$

In relation to the character, it can also rely upon Howard Gardner's thoughts like how the mind develops and maintains such as how people learn, create, lead, change their mind, and how the mind is used so that people may have good characters. ${ }^{6}$ In terms of habit of the mind, Gardner proposed five ways of minds, they are (1) the disciplined mind, (2) the synthesizing mind, (3) the creating mind, (4) the respectful mind , and (5) the ethical mind. ${ }^{7}$ Similar to this view, Lickona explains good character that consists of knowing the good, desiring the good, and

${ }^{3}$ Martin E. PSeligman, dan Mihaly Csikszentmihalyi, Positive Psychology: An Introduction, American Psychological Association, Vol 55. No. 1. 2000, 5-14.

${ }^{4}$ Howard Gardner, Mihaly Csikszentmihalyi, and William Damon, Good Work: When Excellence and Ethics Meet, (New York: Basic Books. 2001), p. 3.

${ }^{5}$ Shelly L Gableand Jonathan Haidt, What (and Why) Is Positive Psychology? The Educational Publishing Foundation, Vol. 9, No. 2, 2005, 103-110.

${ }^{6}$ Howard Gardner, 5 Minds for the Future,(Boston: Harvard Business School Publishing, 2008), p. 1-5.

${ }^{77}$ Howard Gardner, op.cit. p. 3-4. 
doing the good. He also said that there are three kinds of character habits, namely habits of the mind, habits of the heart, and habits of action. ${ }^{8}$ All three are necessary for leading a moral life and maturity. Good characters are essential pillar of character education that should be addressed by all education institutes. Character education is a national movement creating schools that foster ethical, responsible, and caring young people by modeling and teaching good character through an emphasis on universal values that we all share. ${ }^{9}$ This is a national program that can make all states design and develop creative model of character education based on certain condition in specific area.

Character education is the deliberate use of all dimensions of school life to foster optimal character development. ${ }^{10}$ This comprehensive approach to character education utilizes every aspect of schooling where the content of the curriculum, the process of instruction, the quality of relationships, the handling of discipline, the conduct of cocurricular activities and the ethos of the total school environment to foster good character in all school members. Therefore, school should teach morality. School will inevitably envelop its students in a moral climate. This just "comes with the territory," if a moral climate always exists in schools, then educators should work towards implementing good character into schools. ${ }^{11}$ Forming students' character in school is imperative to avoid moral deterioration and decadence.

At the higher education level, State Islamic University (UIN) Alauddin has developed character building training program that focuses on four pillars character; (1) Intrapersonal relationship; strengthening self, (2) relationship between self and others (interpersonal), relationship between self and environment (naturalistic), and relationship between self and Lord (existential-spiritual). ${ }^{12}$ In high

${ }^{8}$ Thomas Lickona, 1991, Educating for Character: How Our Schools can Teach Respect and Responsibility, (New York: Bantam Books, 1991), p. 51.

${ }^{9}$ Mike Frye et all, Character Education: Informational Handbook \& Guide for Support and Implementation of the Student Citizen Act of 2001 (Character and Civic Education), (North Carolina: Department of Public Instruction, 2002), p. 2.

${ }^{10}$ See, for example: Battistich, V., Schaps, E., Watson, M., Solomon, D., \& Lewis, C. (2000). Effects of the Child Development Project on students' drug use and other problem behaviors. Journal of Primary Prevention, 21, 75-99.

${ }^{11}$ Tiffany Gray, Character Education in Schools, Essai, Vol. 7, 2009, Article 21, p. 56.

${ }^{12}$ Muhammad Yaumi, Pilar-pilar Pendidikan Karakter, (Makassar: Alauddin Press, 2013), p. 56. 
school, Boarding School Darunnajah has developed acharacter education principles that are reflected in five pillars, namely sincerity, honesty, modesty, independence, brotherhood among Muslims (Islamic brotherhood), and freedom. To build the five pillars, Boarding School Darunnajah uses three methods of implementation which include (1) knowledge that are constructed through the integration of character values into the curriculum, (2) conditional, which was formed from the construction of boarding culture, and (3) worship practices, developed through extracurricular activities, organization, daily life, and social activities. $^{13}$ The other school is Model Islamic High School (MANModel) of Makassar where the character values have been implementing since 2011 by involving teachers, students, and parents to support the program. The school, however, has not been evaluated about the effectiveness of character education implementation, integration model as well as character values designed, implemented, and managed in this school.

Based on the various views, the main problem statement of this study can be formulated such as "how is the character education values implemented in school setting?" which is specified as follows:

1. How is the integration of character education values into the teachers' lesson plan provided in all grades?

2. How is the implementation of character education in classroom teaching and learning process?

3. How does the character education values work in school academic rules?

The study aims at finding the character education values that work in Model Islamic High School of Makassar after implementing character education during the last four years in school setting. It is expected to give contribution for the theory of knowledge, moral (akhlaq), and behavior construction. The result of this study is beneficial for the curriculum development of Islamic High School in general and especially for the internal school curriculum improvement. In addition, the result of this study is to contribute the integration model of character

${ }^{13}$ Duna Izfanna and Nik Ahmad Hisyam, A Comprehensive Approach in Developing Akhlaq: A case study on the implementation of character education at Pondok Pesantren Darunnajah, Multicultural Education \& Technology Journal,Vol. 6 No. 2, 2012pp. 77-86. 
education values for the teachers' lesson plan, instructional implementation in classroom setting, and implementing school academic rules to form students' lifestyles that are based on good character.

This study used case study research. It is a qualitative research approach in which researchers focus on a unit of study known as bounded system (e.g., individual teachers, classroom, or a school). ${ }^{14}$ Case study is used to study some events, situations, programs, and activities that are of special interest. ${ }^{15} \mathrm{~A}$ good case study brings a phenomenon to life for readers and helps them understand its meaning. ${ }^{16}$ A case study research also involves the study of an issue explored through one or more cases within a bounded system (i.e., a setting, a context). ${ }^{17}$ This study is focused on program of character education values that are integrated into lesson plan, teaching and learning process in the classroom, and the school academic rules. Fifty lesson plans were collected, twenty six teachers of Islamic Senior High School 2 (MAN 2) of Makassar were interviewed and observed to collect data about the integration model of character education values, the implementation of character education in classroom teaching and learning process, and character education values that work in school academic rules.The collected data were analyzed using qualitative data analysis procedures as such as data reduction, data display, conclution drawing and verification. ${ }^{18}$

\section{Research Results}

The research results involve three components; lesson plans and materials, classroom procedure, and classroom-wide academic rules. Teaching plans and materials (lesson plan) in this study means a teacher's

${ }^{14}$ L.R. Gay, Geoffrey E Mills, and Peter Airasian, Educational Research: Competencies for Analysis and Applications, (Ninth Edition; Columbus Ohio: Pearson, 2009), p. 426.

15 Dawson R. Hancockand BobAlgozzine,Doing Case Study Research: Apractical Guide for Beginning Researchers, (New York: Teachers College Press, 2006), p. 17.

${ }^{16}$ Meredith D. Gall, Joyce P. Gall, and Walter R. Borg, Educational Research: An Introduction (Seventh Edition; Boston: Allyn \& Bacon, 2003), p.434.

${ }^{17}$ John W. Creswell, Qualitative Inquiry \& Research Design: Choosing Among Five Approaches, (Second Edition, Thousand Oaks, California: Sage Publications, Inc., 2007), p.73.

${ }^{18}$ See, Matthew B.Miles and A Michael Huberman,Qualitative Data Analysis,(London: Sage Publications, 1994), pp. 10-11. 
detailed description of the course of instruction that integrate character education values to be used for one or more meetings. Classroom procedures (some people called instructional strategy) are the classroom instructional activities that include classroom management activity, media and learning resources usage, method, and learning evaluation by integrating character education values into those activities. Then, classroom-wide academic rule is a norm standard that support cultural values to be implemented in the classroom school program.

\section{The Integration of Cultural Education Values in Lesson Plan}

Based on the data obtained through document study of fifty lesson plans made by twenty six teachers from all grades (first, second, and third grades) indicated that there are eighteen cultural values to be included into the lesson plans, as follows: religious, honest, tolerant, discipline, hard working, creative, independent, democratic curiosity, spirit ofnationality, love to motherland, appreciation of achievement, friendly and communicative, peaceful, love to read, environmental care, social care, responsibility. Each lesson plan contains five to six character values depending on the provided activities. The description of the character values are as follows:

\section{Table 1. Cultural Education Values in Lesson Plan}

\begin{tabular}{|l|l|}
\hline \multicolumn{1}{|c|}{$\begin{array}{c}\text { CHARACTER } \\
\text { VALUES }\end{array}$} & \multicolumn{1}{|c|}{ DESCRIPTION OF ACTIVITIES } \\
\hline 1. Religious & $\begin{array}{l}\text { Three to five students participate into the holy quran } \\
\text { recitation for about ten minutes. Then the teacher explains } \\
\text { the meaning of each verse. }\end{array}$ \\
\hline 2. Honest & $\begin{array}{l}\text { Seeking a broader and deeper information about the } \\
\text { topic/theme of the material to be studied by applying } \\
\text { learning principles and learning from various sources }\end{array}$ \\
\hline 3. Tolerant & $\begin{array}{l}\text { Having interaction among the learners, learners and } \\
\text { teachers, learning environment, and other learning } \\
\text { resources. Also, when engaging learners actively in any } \\
\text { learning activities. }\end{array}$ \\
\hline 4. Discipline & $\begin{array}{l}\text { Submitting the task on time, using uniform, as well as } \\
\text { involving to instructional activities }\end{array}$ \\
\hline 5. Hard working & $\begin{array}{l}\text { Doing experiment in the laboratory, studium, and simple } \\
\text { field observation, doing reading and writing task. }\end{array}$ \\
\hline 6. Creative & $\begin{array}{l}\text { Taking an opportunity to think, analyze, resolve } \\
\text { problems, and actwithout fear and making good report }\end{array}$ \\
\hline
\end{tabular}


Muhammad Yaumi \&L Rustam Husain

\begin{tabular}{|c|c|}
\hline & $\begin{array}{l}\text { exploration conducted bothorally } \text { and in writing, } \\
\text { individually or in groups. }\end{array}$ \\
\hline 7. Independent & $\begin{array}{l}\text { Taking a part to present and complete individual work and } \\
\text { involving into the activities that foster pride and self- } \\
\text { confidence. }\end{array}$ \\
\hline 8. Democratic & $\begin{array}{l}\text { Involving into the cooperative and collaborative learning } \\
\text { activities and competingin a healthy way to improve } \\
\text { learning achievement. }\end{array}$ \\
\hline 9. Curiosity & $\begin{array}{l}\text { Asking forpositive feedback and reinforcement in the form } \\
\text { of oral, written, sign, and present to the success of students. } \\
\text { Also asking to confirm the results of exploration and } \\
\text { elaboration through a variety of sources. }\end{array}$ \\
\hline $\begin{array}{l}\text { 10. The spirit of } \\
\text { Nationality }\end{array}$ & $\begin{array}{l}\text { Singing a national anthem, exploring national flora and } \\
\text { fauna, animal, and territorial potention to be developed, and } \\
\text { learning the biography of national heroes. }\end{array}$ \\
\hline 11. Love to Motherland & $\begin{array}{l}\text { Having good way of thinking, loyalty, awareness, and } \\
\text { appreciation to the national and local languages, physical } \\
\text { environment, social, cultural, economic, and political view. }\end{array}$ \\
\hline $\begin{array}{l}\text { 12. Appreciation of } \\
\text { Achievement }\end{array}$ & $\begin{array}{l}\text { Doing exhibitions, tournaments, festivals, and the resulting } \\
\text { product. Also collecting trophy, sertificate, and other forms } \\
\text { of reward on quiz competition and championship. }\end{array}$ \\
\hline $\begin{array}{l}\text { 13. Friendly and } \\
\text { communicative }\end{array}$ & $\begin{array}{l}\text { Doing assignments, discussions, and others } \\
\text { to come up with new ideas both orally and in writing. } \\
\text { Appreciating to each view and opinion and giving response } \\
\text { to the question in a good communicative way. }\end{array}$ \\
\hline 14. Peaceful & $\begin{array}{l}\text { Keeping attitudes, words, and actions that lead to the } \\
\text { others feel happy and secureing the presence of self in a } \\
\text { certain place. }\end{array}$ \\
\hline 15. love to read & $\begin{array}{l}\text { Building habit to provide special time for reading various } \\
\text { kinds of resources including novel, biography, story, etc. }\end{array}$ \\
\hline 16. Environmental care & $\begin{array}{l}\text { Involving to the instructional activities to increase attitudes } \\
\text { andactions of preventing damage tothe surrounding natural } \\
\text { environment and improve natural damage that has occurred. }\end{array}$ \\
\hline 17. Social Care & $\begin{array}{l}\text { Engaging to the instructional activities that bring to the real } \\
\text { world situation and helpother people andcommunity in } \\
\text { need. }\end{array}$ \\
\hline 18. Responsibility & $\begin{array}{l}\text { Being active to join and follow various instructional } \\
\text { activities, presenting results of individual and group work, } \\
\text { doing exhibitions, tournaments, festivals, } \\
\text { and the resulting product, and submitting all the tasks on } \\
\text { time to get a good grade. }\end{array}$ \\
\hline
\end{tabular}

Data obtained from interview also indicated that there were two types of lesson plans; lesson plan that is based on 2006 curriculum (KTSP) like 
being provided by the third grade teachers and lesson plans that is based on 2013 curriculum, which was prepared by the first and second grade teachers. In addition, the interview result indicated that integration steps include analysis, selecting topic, determining character values and designing task and assignment, as described in figure 1 below.

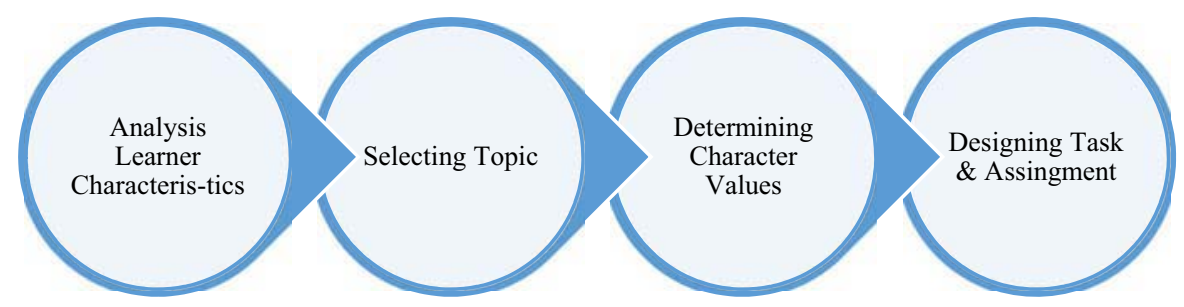

Figure 1. Integration Steps of Cultural Education Values

Learner characteristics consist of general and specific ones. General characteristics include gender, tribe, social status, and educational background and the specific characteristics involve learning styles, multiple intelligences, and motivation. However, teachers did not analyze all the characteristics. Educational background and gender are the focused emphasis because of giving a significant impact to the character education. Selecting topic of instructional materials became a fundamental attention to determine the suitable character values to be developed. The difference of the topic would give different character values to be integrated in lesson plan. Besides that, determining character values that are suitable with the learner characteristics and topic of instructional materials would be very important to have relevant resources that best address to character development. In addition, designing task and assignment would support the accuracy and acceleration of character building in individual and group cultures.

\section{Instructional Strategy}

Instructional strategy refers to the implementation of character education in classroom teaching and learning process through preliminary, primary, and closing activities. Preliminary activities are opening classroom by greetings, giving motivation, apperception, and 
explaining about instructional objectives. In KTSP (Educational Unit Curriculum), the primary activities include exploration, elaboration, and confirmation activities. On the contrary, 2013 curriculum accommodates observing, questioning, associating, experimenting, and networking skills to implement primary activities. Then, closing activities include various activities such as summarizing, feedback and evaluating, and follow-up activities to have students extend their knowledge, attitude, and skills.

Although the integration of the character values has been made in lesson plan, not all the values can be implemented in teaching and learning process. The lack of instructional activities, teacher centered approach, and limitation of time allotment for each class made most of character education values difficult to be applied into the classroom setting. Each grade of MAN 2 has discrete culture values to be integrated in the classroom setting. Every teacher has different way to integrate the character values into teaching and learning process. As stated by Laode Riasi "as long as I do, the integration of cultural values is conducted through content and activity. The content includes the meaning of akhlaq taken from the verses 38: 46 that talks about the highest level of akhlak is informing about the life in hereafter. The other verses is taken from 68:4 that talks about tha model of good akhlak is Prophet Muhammad pbu. The activity is integrated through methods of teaching such as discussion that consists of how to appreciate views of others, cut the talkings, and add the comments politely" 19

Character education values is also integrated through discussion forum and cases, as stated by Kaharuddin that "when I conducted discussion on political aspect such as curruption, national law, and employment the students were enthusiastic in expressing their point of view. I suggested them to be tollerant and respect to others even the view is opposite one another. The case of a country that is collapsed becouse of corruption, the gave some wonderful ideas to solve the problems." 20 Similar to this statement, Erniwati stated that "we integrated character education values from many ways. As a vice principal of curriculum and

${ }^{19}$ Translated from the Indonesian language stated by Laode Riasi a supervisor of OSIS and a teacher of Aqida-Akhlak subject at the second grade of MAN Model Makassar, Interviewed on July 24, 2014.

${ }^{20}$ Translated from the Indonesian language stated by Kaharuddin a supervisor of OSIS and a teacher of PPKN subject at the first grade of MAN Model Makassar, Interviewed on July 24, 2014. 
academic affairs, I always suggest and facilitate our teachers to integrate the character values. Based on my observation, the teachers in this school have integrated through contents, instructional activites, discussion, sharing opinion such as in Scout forum and telling about biography of great people in the world. We are optimistic to integrate the character values through internal instructional teaching and learning and external or extracurricular activites such in scout, OSIS, arts, and self development activities. ${ }^{21}$

Based on the informant's statements and the example of the above views collected through interview, the character education values can be integrated through content, activity, case, discussion, experience sharing, and autobiography. The first phase of character values implementation in classroom setting is content integration that refers to subject matter, instructional materials, and learning resources. This phase is choosing some suitable materials, which are relevant to specific character. The students learn the character values, collecting concept, and constructing their own knowledge.

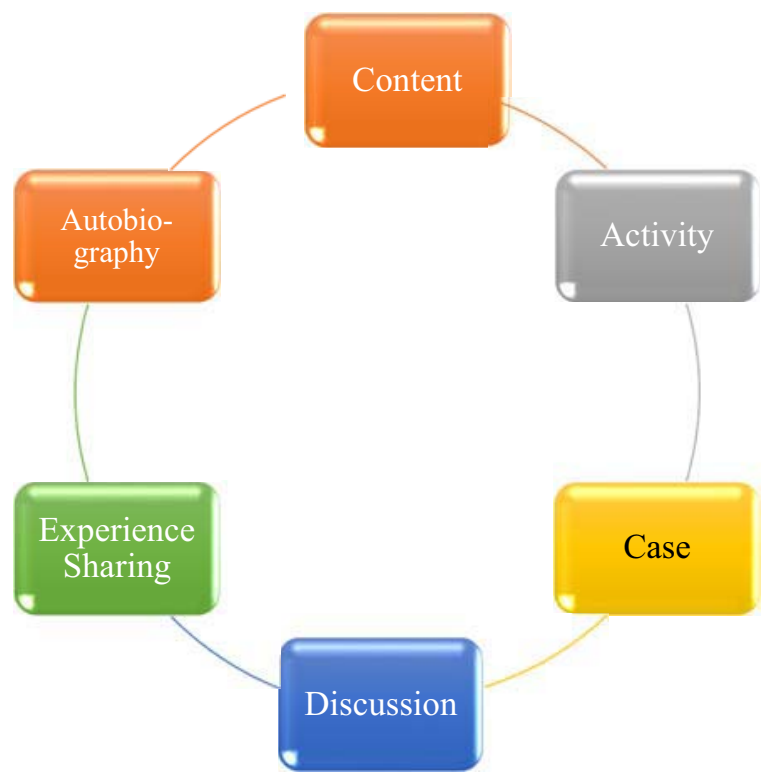

Figure 2.

Integration Phases of Character Values into Teaching and Learning Process

${ }^{21}$ Translated from the Indonesian language stated by Erniwati a vice principal of curriculum and academic affairs of MAN Model Makassar, Interviewed on July 27, 2014. 
The second phase is doing activities to experience and internalize the values. The students did not only understand and comprehend the values but also did them through various provided activities. They acculturated the value to become a habit in daily life. The third phase is solving the cases which had been designed to promote the character values. The teacher collected some relevant cases and gave the students to overcome in small group or as an individual work. The fourth phase is conducting discussion. The teacher gave instruction how to ask questions, give agreement and disagreement based on the polite ways that indicated positive and good character. The fifth phase is allocating the time for sharing experience. The students were asked to choose the suitable real story to share to the others, and the teachers facilitated them and emphasized some relevant character values such as bravery, responsibility, honesty, and so on. The last phase reading autobiography that told about some great people. The students were facilitated to have interesting biography of people s/he knew and took a lesson from the story.

Observation result indicated that the character values that have been implemented through integrating content, doing activities, solving the cases, conducting discussion, allocating the time for sharing experience, and reading autobiography are different from one grade to the others. The first grade implemented nine character values, the second grade implemented twelve values, and the third grade involved twelve values. The detaildescription of the character values are given at following table 2 .

Tabel 2. Integration of Cultural Values into the Classroom setting

\begin{tabular}{|c|l|}
\hline GRADE/YEAR & \multicolumn{1}{|c|}{ CULTURE VALUE } \\
\hline FIRST (I) & $\begin{array}{l}\text { Religious, trustworthy, respect, diligent, } \\
\text { fairness/justice, care, integrity, } \\
\text { responsible, honesty. }\end{array}$ \\
\hline Second (II) & $\begin{array}{l}\text { Religious, trustworthy, respectfull, diligent, } \\
\text { fairn, care, integrity, responsible, honest, } \\
\text { love to motherland, courage, and integrity. }\end{array}$ \\
\hline Third (III) & $\begin{array}{l}\text { Religious, trustworthy, respect, diligent, } \\
\text { fair, care, integrity, responsible, honesty, } \\
\text { citizenship, courage, and diligent. }\end{array}$ \\
\hline
\end{tabular}


Based on the table 2 above, there are eleven character education values that have been integrated into the classroom, namely religious, trustworthy, respect, diligent, fairness/justice, care, integrity, responsible, honesty, citizenship, courage, integrity. From those characters, there are nine characters that have been integrated into the first grade classroom, thirteen in the second grade, and twelve in the third grade. The values such as trustworthy, diligent, fairness/justice, integrity, courage are not written in the lesson plan but are implemented into the classroom setting.

\section{Academic Rules}

The character education values are not only integrated into the lesson plan and instructional strategy, but also in academic rules that support classroom setting and extracurricular activities. Assignment submission, wearing clothes (pants, skirts, shirt, and shoes), hair size, truant and retarding are part of academic rules in the classroom. The other activities such as flag ceremony, scout, Red Cross, intra-school organization, and self-development are extracurricular part. Based on the observation and interview results the cultural values that work in MAN Model Makassar consist of twelve character values. Bakri, a boy scout supervisor said that "we build the attitude of discipline, tollerant, friendly, responsible, spirit of nationality, social care, independent, creativer, hard working through encampment program. In the program we play game, sleuth, bonfire, climb mountain, and many other programs we conduct to bulid and maintain good character"22

Similar to the boy scout program, the other statement given by Ahmad Hasan who said that "Togetherness is a good example of my experience in leading this school. We (I and my academic staffs) care about working together, coming on time, care of selves, others, environment, and the most important is relationship with God in daily life. Good attitude and great character are the essential parts of our priority to be establish in this school. We integrated some character values in teaching and learning and extracurricular activities as well. I always supervise the teachers to be able not only in designing lesson plan and implementing the instructional activities, but also supporting other

${ }^{22}$ Translated from the Indonesian language stated by Bakri a supervisor of boy scout of MAN Model Makassar, Interviewed on February 10, 2015. 
extracurricular activities to suport school climate surrounded by good character." 23

The data collected through observation indicated that some character values integrated through extracurricular activities like implemented through OSIS, scout, self-development program are disciplines, care (social and environmental care), tolerant, friendly and communicative, responsible. The students were supposed to come on time, using uniform, and submit the task based on the given deadline to maintain their discipline. The punishment was given to those who couldnot fulfill the rules. Beside that, the rules also covered the way how the students care each other and with the environment. When someone needed a help, the others gave him/her a good help. If there was atrashscattered in the classroom, everyone cares to clean up the classroom.

From the perspective of students characteristics, they came from various cultures and tradition, tribes, language, social, and even geographical status. The rules covers also living in harmony and in tolerant way. The group classification for classroom discussion and assignment should consider these characteristics. Then, the rules regulated also the imprtance of being friendly, where everybody in the classroom accosted each other, gave smile, and communicates to share new information. The last but not least is character value of responsibility, whereevery schoolday, the 4-5 students were scheduled to have a day for cleaning the classroom (this school does not have any cleaning service member), setting the classroom, and cleaning the whiteboad or chalkboard after each session of the class finished. This task is to gain and build the character of responsibility.

\section{E. Conclusion}

Based on the findings explained above, the character education values that work in the classrooms of MAN 2 Makassar can be seen from three components; lesson plan, classroom procedure, and academic rules. The character education values writen in the lesson plan consist of eighteen characters, they are religious, honest, tolerant, discipline, hard

${ }^{23}$ Translated from the Indonesian language stated by Ahmad Hasan a principal of MAN Model Makassar, Interviewed on February 10, 2015. 
working, creative, independent, democratic, curiousity, the spirit ofnation, love to motherland, appreciation of achievement, friendly and communicative, peaceful, love to read, environmental care, social care, responsibility. The ways of integrating the cultural values through desinging lesson plans are analysis learners' characteristics, selecting topic, determining character values and designing task and assignment. The implementation of character education in the classroom teaching and learning process is conducted through content integration, learning activity, cases, discussion, experience sharing, and autobiography.

The character education values that work during the implementation of the subject in the classroom are religious, trustworthy, respect, diligent, fairness/justice, care, integrity, responsible, honesty, citizenship, courage, integrity. there are nine values implemented at the first grade, thirteen values in the second grade, and twelve values implemented in the third grade. The last, the values that work in the academic rules are disciplines, care, tolerant, friendly and communicative, responsible. 


\section{REFERENCE}

Dewantoro, Ki Hajar. Pendidikan, Cetakan Kedua. Majelis Luhur Persatuan Taman Siswa Yogyakarta, 1977.

Gay, L.R., Mills, Geoffrey E, and Airasian, Peter. Educational Research: Competencies for Analysis and Applications. Columbus: Pearson. 2009.

Gable, Shelly L. and Haidt, Jonathan. What (and Why) Is Positive Psychology? the Educational Publishing Foundation. 2005, Vol. 9, No. 2, 103-110.

Gardner, Howard. Frames of Mind. New York: Basic Books Inc. 1983.

Gardner, Howard. Intelligence Reframed, New York: Basic Books. 1999.

Gardner, H., Mihalyi, Mihaly C., and Damon, William. Good Work: When Excellence and Ethics Meet. New York: Basic Books. 2001.

Gardner, Howard. 5 Minds for the Future. Boston: Harvard Business School Publishing. 2008.

Gay, L.R., Mills, Geoffrey E, and Airasian, Peter. Educational Research: Competencies for Analysis and Applications. Columbus: Pearson. 2009.

Hancock, Dawson R. and Algozzine Bob. Doing Case Study Research: Apractical Guide for Beginning Researchers. New York: Teachers College Press. 2006.

Lickona, Thomas. Educating for Character: How Our Schools can Teach Respect and Responsibility. New York: Bantam Books. 1991.

Miles, Matthew B and Huberman, A Michael.Qualitative Data Analysis. London: Sage Publications. 1994.

Seligman, Martin E. P., dan Csikszentmihalyi, Mihaly. Positive Psychology: An Introduction. American Psychological Association. Lnc., 2000, Voh 55. No. 1. 5-14. 